\title{
MOTIVASI INTRINSIK, MOTIVASI EKSTRINSIK, KOMPETENSI DAN KINERJA GURU
}

\author{
Yusra Abbas \\ Fakultas Keguruan dan Ilmu Pendidikan \\ Universitas Muhammadiyah Maluku Utara \\ Jl. KHA. Dahlan Kelurahan Sasa, Ternate \\ yusra_abbas@yahoo.co.id
}

\begin{abstract}
Abstrak
These research purposes are: (1) explore the relationship between intrinsic motivation with teacher's performance; (2) explore the relationship between extrinsic motivation with teacher's performance; (3) explore the relationship between teacher's competences withteacher's performance. Data was collected through intrinsic motivarion scale, extrinsic motivation scale, teacher's competency scale and performance measurement. This research is quantitative research with correlational approach. This research used cluster sampling to select the sample from the population. The population of this research was 160 junior high school teachers in Ternate Utara, while the samples were 105 junior high school teachers. Research results show: (1) there was significant correlation between intrinsic motivation with teacher's performance; (2) there was significant correlation between extrinsic motivation with teacher's performance; (3) there was significant correlation between teacher's competences with teacher's performance.
\end{abstract}

Keywords: competence, extrinsic motivation, intrinsic motivation, teacher's performance

\begin{abstract}
Abstrak
Penelitian ini bertujuan untuk:(1) Mengetahui hubungan antara motivasi intrinsic kerja guru dengan kinerja guru; (2) Mengetahui hubungan antara motivasi ekstrinsik kerja guru dengan kinerja guru; (3) Mengetahui hubungan antara kompetensi guru dengan kinerja guru. Data dikumpulkan dengan beberapa skala yaitu: skala motivasi intrinsik, skala motivasi ekstrinsik,
\end{abstract}


skala kompetensi dan pengukuran kinerja. Penelitian ini menggunakan pendekatan penelitian kuantitatif korelasional. Populasi dalam penelitian adalah guru-guru SMP Kota Ternate Utara yang berjumlah 160 orang, Sedangkan sampel dalam penelitian adalah sebagian dari guru SMP Kota Ternate Utara yang diambil melalui teknik cluster sampling sejumlah 105 orang. Hasil penelitian menunjukkan bahwa: (1) motivasi intrinsic memiliki pengaruh yang signifikan dengan kinerja guru, (2) terdapat hubungan yang positif antara motivasi ekstrinsik dengan kinerja guru. (3) terdapat hubungan positif yang signifikan antara kompetensi dengan kinerja guru.

Kata kunci: motivasi intrinsik, motivasi ekstrinsik, kompetensi, dan kinerja guru.

\section{Pendahuluan}

Sumber daya manusia di Indonesia sangat diperlukan untuk mengelola pendidikan. Manusia yang dibutuhkan tersebut adalah manusia terdidik dan bermutu. Untuk itu diperlukan pendidikan yang bermutu. Pendidikan menurut undang-undang nomor 20 tahun 2003 Bab I pasal 1 ayat (1) tentang Sistem Pendidikan Nasional adalah usaha sadar dan terencana untuk mewujudkan suasana belajar dan proses pembelajaran agar peserta didik secara aktif mengembangkan potensi dirinya untuk memiliki kekuatan spiritual keagamaan, pengendalian diri, kepribadian, kecerdasan, akhlak mulia, serta ketrampilan yang diperlukan dirinya, masyarakat, bangsa, dan negara (Depdiknas, 2003). Mencermati pengertian pendidikan di atas, maka pendidikan dapat diartikan sebagai usaha manusia untuk membina kepribadiannya sesuai dengan nilai-nilai yang ada dalam masyarakat dan kebudayaannya.

Guru memiliki peran yang penting dan strategis, dan bertanggung jawab dalam usaha pencapaian tujuan pendidikan nasional. Depdiknas (2005), Undang-Undang No. 14 tahun 2005 tentang Guru dan Dosen Pasal 4 menegaskan bahwa peran guru sebagai agen pembelajaran berfungsi untuk meningkatkan mutu pendidikan nasional. Untuk dapat melaksanakan fungsinya dengan baik, guru wajib untuk memiliki syarat tertentu, di antaranya adalah harus memiliki kompetensi yang memadai dan motivasi kerja yang baik.

Usman (2009) menyatakan bahwa tugas guru sebagai profesi meliputi mendidik, mengajar, dan melatih. Mendidik berarti meneruskan dan mengembangkan nilai-nilai 
hidup, sedangkan mengajar berarti meneruskan dan mengembangkan ilmu pengetahuan dan teknologi. Melatih berarti mengembangkan keterampilanketerampilan pada siswa. Senada dengan Usman, Suyanto dan Hisyam (2000) menyatakan bahwa guru merupakan pihak yang paling sering dituding sebagai orang yang paling bertanggung jawab terhadap kualitas pendidikan. Hal ini berarti bahwa kehadiran dan profesionalisme seorang guru sangat berpengaruh dan menentukan dalam mewujudkan cita-cita pembangunan nasional terutama mewujudkan program pendidikan nasional.

Dengan demikian, peranan guru sangat menentukan dalam usaha peningkatan mutu pendidikan formal. Untuk itu guru sebagai agen pembelajaran dituntut untuk mampu menyelenggarakan proses pembelajaran dengan sebaik-baiknya dalam kerangka pembangunan pendidikan. Guru mempunyai fungsi dan peran yang sangat strategis dalam pembangunan di bidang pendidikan, maka profesi guru perlu dikembangkan sebagai profesi yang bermartabat.

Guru mempunyai tugas dan tanggung jawab yang berat. Tugas dan tanggung jawab tersebut belum diimbangi dengan motivasi intrinsik kerja guru, motivasi ekstrinsik kerja guru dan kompetensi, sebagaimana fakta yang terjadi pada guruguru Sekolah Menengah Pertama (SMP) di kota Ternate Utara. Untuk itu, faktorfaktor yang mempengaruhi kinerja guru dipandang perlu untuk dipelajari, ditelaah dan dikaji secara mendalam agar dapat memberikan gambaran yang jelas, faktor yang lebih berperan dan urgen yang mempengaruhi kinerja guru.

Berdasarkan pengamatan dan pembicaraan dengan sebagian kepala sekolah dan guru sekolah menengah pertama (SMP) di kota Ternate Utara diketahui bahwa guru yang ada di wilayah tersebut sebagian belum memiliki kinerja yang maksimal. (1) Kurangnya koordinasi antara pimpinan dan bawahan, sehingga disiplin kerja atau etos kerja menurun misalnya guru datang tidak tepat waktu dan mengajar tidak menggunakan perangkat pembelajaran, serta jarang memperoleh tugas-tugas tambahan dari kepala sekolah mengakibatkan kinerja guru tersebut menurun. (2) Sebagian guru belum menguasai landasan kependidikan, misalnya: Pada saat mengajar guru belum kreatif menggunakan media pembelajaran sesuai dengan materi yang diajarkan. (3) Sebagian guru belum mampu melaksanakan fungsi dan tugas sebagai pendidik dan pengajar, misalnya penanaman konsep dasar pembelajaran yang memadai/sesuai. (4) Pemda dalam hal ini dinas pendidikan setempat lebih mengutamakan kompetensi misalnya melaksanakan workshop dan MGMP di banding memotivasi atau memfasilitasi guru dalam mengembangkan karier secara mandiri sebagai guru bidang studi contoh sarana praktikum atau alat peraga. 
Data di atas menunjukkan bahwa motivasi intrinsik, motivasi ekstrinsik kerja guru dan kompetensi guru dengan kinerja guru di (SMP) kota Ternate Utara dalam menjalankan tugas sehari-hari juga sangat bervariasi, ada yang mempunyai motivasi intrinsik dan motivasi ekstrinsik kerja guru tinggi dan sedang tetapi ada yang motivasi kerjanya rendah. Ada yang memiliki kompetensi yang tinggi dan sedang tetapi ada juga yang memiliki kompetensi rendah. Data di atas dapat dikatakan bahwa ada permasalahan yang kompleks dalam hubungan dengan kinerja guru SMP di kota Ternate Utara sehingga perlu dikaji tentang "Hubungan antara motivasi intrinsik kerja guru, motivasi ekstrinsik kerja guru dan kompetensi guru dengan kinerja guru SMP di kota Ternate Utara".

Berdasarkan beberapa penelitian terdahulu menunjukkan adanya kontribusi motivasi kerja dengan kinerja guru. Penelitian yang dilakukan oleh Subani (2009) menunjukkan bahwa terdapat pengaruh positif dan signifikan faktor motivasi kerja terhadap kinerja guru. Oleh karena itu, semakin bertambah nilai faktor motivasi kerja maka semakin bertambah nilai kinerja guru. Terdapat pula pengaruh positif dan signifikan faktor kompetensi guru terhadap kinerja guru. Dengan demikian, semakin bertambah nilai faktor kompetensi maka semakin bertambah nilai kinerja guru.

Sukmalana (Ridwan, 2009) menyatakan bahwa kemampuan dan motivasi adalah sebagai faktor-faktor yang berinteraksi dengan kinerja. Kemampuan seseorang dapat ditentukan oleh keterampilan dan pengetahuan, sedangkan keterampilan dapat dipengaruhi oleh kecakapan. Kepribadian dan pengetahuan dapat dipengaruhi oleh pendidikan, pengalaman latihan dan minat. Motivasi pada dasarnya dapat bersumber pada diri seseorang (motivasi intrinsik) dan dapat pula bersumber dari luar diri seseorang (motivasi ekstrinsik). Faktor-faktor motivasi tersebut dapat berdampak positif atau dapat pula berdampak negatif bagi seorang guru. Dalam hal ini, seorang guru dituntut memiliki motivasi intrinsik kerja guru, motivasi ekstrinsik kerja guru dan kompetensi yang memadai untuk dapat menampilkan kemampuan dan hasil kerja yang memadai pula. Jika guru tidak menguasai bahan yang akan diajarkan dan peserta didik hanya disuruh mencatat atau mengerjakan tugas-tugas, guru tidak mempunyai bahan ajar yang ditulisnya (buku pegangan) dan guru yang bersangkutan merasa risih dan suka gengsi menggunakan literatur lain, tidak menguasai landasan kependidikan, tidak mampu melaksanakan fungsi dan tugas sebagai pendidik dan pengajar, tidak mempersiapkan apa yang akan diajarkan, mempunyai motivasi kerja yang rendah, kurang memiliki inisiatif dan kurang kreatif dalam mengadakan dan menulis bahan ajar, kurang produktif, kurang supel dalam pergaulan dan kurang informatif, maka peserta didik cenderung tidak tertarik untuk belajar dengan sungguh- 
sungguh atau menjadi malas. Dalam hal ini kinerja guru lemah dan memprihatinkan.

Fakta menunjukkan bahwa terdapat banyak kesenjangan untuk menilai kinerja guru. Evaluasi tahunan tentang kinerja guru yang dilaksanakan entah oleh setiap unit sekolah maupun oleh dinas Pendidikan Nasional Kota Ternate masih bersifat normatif. Artinya, berbagai permasalahan kinerja yang dihadapi guru relatif diidentifikasi dan didokumentasikan secara baik tanpa meneliti faktor-faktor apa saja yang mempengaruhi dan bagaimana hubungan faktor-faktor tersebut dengan kinerja guru. Keterkaitan antara motivasi intrinsik kerja guru, motivasi ekstrinsik kerja guru dan kompetensi dengan kinerja guru tersebut memperlihatkan model hubungan fungsional yang dapat dilihat pada gambar 1 di bawah ini:

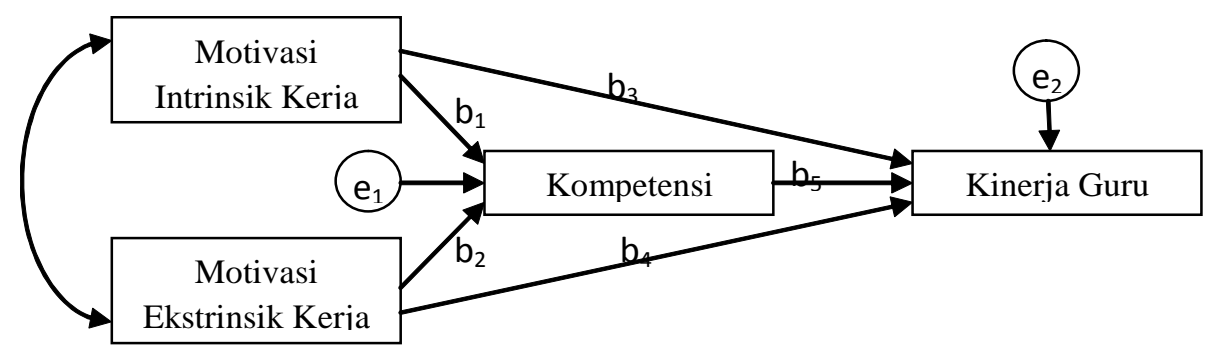

Gambar 1

Hubungan antara motivasi intrinsik kerja guru, motivasi ekstrinsik kerja guru dan kompetensi guru, dengan kinerja guru.

\section{Metode Penelitian}

Populasi menurut Sugiyono (2009) adalah: Wilayah generalisasi yang terdiri atas obyek/subyek yang mempunyai kualitas dan karakteristik tertentu yang ditetapkan oleh peneliti untuk dipelajari dan kemudian ditarik kesimpulannya, bila populasi besar, dan peneliti tidak mungkin mempelajari semua yang ada pada populasi, misalnya karena keterbatasan dana, tenaga dan waktu.

Ppopulasi dalam penelitian ini adalah guru SMPkota Ternate Utara berjumlah 160 guru dari 5 SMP Kota Ternate Utara, rincian sekolah dan guru dalam penelitian ini dapat di lihat pada tabel 3 berikut ini: 
Tabel 1

Daftar Nama Sekolah dan Jumlah Guru SMP Kota Ternate Utara

\begin{tabular}{llcl}
\hline No Nama sekolah & Jumlah Guru & Keterangan \\
\hline 1 & SMP Negeri 2 Ternate & 62 & Populasi/Sampel \\
2 & SMP Negeri 5 Ternate & 36 & Populasi/Sampel \\
3 & SMP Islam Ternate & 32 & Populasi/Sampel \\
4 & SMP Negeri 10 Ternate & 16 & Populasi \\
5 & SMP Negeri 13 Ternate & 14 & Populasi \\
6 & SMP Muhammadiyah 1 Ternate & 25 & Uji coba \\
7 & SMP Muhammadiyah 2 Ternate & 12 & Uji coba \\
\hline
\end{tabular}

Sampel dalam penelitian ini adalah sebagian dari guru SMP kota Ternate yang diambil melalui teknik Cluster Sampling (Area Sampling) karena jumlah SMP di kota Ternate Utara berjumlah lima sekolah maka pengambilan sampelnya secara random. Teknik ini sering digunakan melalui dua tahap, yaitu tahap pertama menentukan sampel sekolah, dan tahap kedua mementukan guru-guru yang ada di sekolah itu secara sampling juga (Sugiyono, 2009). Teknik ini dapat digambarkan sebagai berikut:

Jumlah sampel yang harus diambil adalah 62 guru SMP Negeri 2 dan 36 guru SMP Negeri 5 kota Ternate serta SMP Islam kota Ternate utara berjumlah 32 guru jadi jumlah sampel keseluruhan adalah 130 guru, namun yang hadir pada saat penelitian sebanyak 105 guru.

Teknik pengumpulan data penelitian dilakukan dengan menggunakan studi dokumentasi dan skala. Studi dokumentasi dalam penelitian ini dimaksudkan sebagai cara mengumpulkan data dengan mempelajari dan mencatat bagian-bagian yang penting dari berbagai risalah resmi yang terdapat baik di lokasi penelitian maupun di dinas Pendidikan Nasional Kota Ternate berupa laporan kegiatan yang relevan dengan fokus penelitian yaitu data mengenai jumlah sekolah, dan data mengenai jumlah guru dan persebarannya di wilayah kotaTernate Utara. Sedangkan skala dimaksudkan untuk mengumpulkan data (motivasi kerja guru intrinsik, Motivasi kerja guru ekstinsik dan kompetensi guru dengan kinerja guru) berupa jawaban tertulis dari guru-guru atas sejumlah pernyataan yang diajukan di dalam skala. Item yang digunakan pada masing-masing variabel penelitian dalam skala hanyalah yang memenuhi syarat valid dan reliabel, sesuai dengan validasi instrumen. Adapun hasil uji reliabilitas pada skala dalam penelitian disajikan dalam tabel sebagai berikut: 
Tabel 2

Hasil Uji Reliabilitas

\begin{tabular}{lccr}
\hline Variabel & Cronbach's Alpha & N of Items & Status \\
\hline Motivasi Intrinsik Kerja Guru & .850 & 15 & Reliabel \\
Motivasi Ekstrinsik Kerja Guru & .897 & 35 & Reliabel \\
Kompetensi Guru & .942 & 40 & Reliabel \\
Kinerja Guru & .882 & 40 & Reliabel \\
\hline
\end{tabular}

Teknik analisis data yang digunakan dalam penelitian ini adalah analisis jalur (Path Analysis). Variabel intervening merupakan variabel antara atau variabel mediator. Variabel penelitian digunakan adalah variabel motivasi kerja guru yang terdiri dari variabel motivasi intrinsik kerja guru, dan variabel motivasi ekstrinsik kerja guru, yang dimediasi oleh variabel kompetensi sebagai faktor pendukung, terhadap kinerja guru. Fungsi dari variabel kompetensi adalah memediasi hubungan antara variabel independen motivasi intrinsik kerja guru dan ekstrinsik kerja guru terhadap variabel dependen kinerja guru.

Analisis jalur merupakan perluasan dari analisis berganda. Analisis jalur juga menggunakan analisis regresi untuk menaksir hubungan kausalitas antar variabel (model causal) yang telah ditetapkan sebelumnya berdasarkan teori. Analisis jalur sendiri tidak dapat digunakan sebagai substansi bagi peneliti untuk melihat hubungan kausalitas antar variabel. Analisis jalur berupaya menentukan pola hubungan antara tiga atau lebih variabel dan tidak dapat digunakan untuk mengkonfirmasi atau menolak hipotesis kausalitas imajiner (Ghozali, 2009).

Model penelitian yang digunakan merupakan seperangkat persamaan linear struktural sebagai analisis faktor pengaruh. Penyusunan model penelitian, diuraikan sebagaimana pendapat Muhadjir (2007) yang menyatakan bahwa logika matematik deduktif set theory telah dikembangkan aplikasinya menggunakan aljabar dan matematiknya, ditampilkan dalam structural equational modeling (SEM). SEM dimaksudkan agar dapat membangun dan mengembangkan kebenaran konstruk (construct truth). Penggunaan SEM secara teknis merupakan struktur sistem persamaan linear dengan mengangkat observed variables dan latent variable. Observed variabel merupakan variabel yang dapat diobservasi dan dapat diukur, sedangkan latent variable merupakan variabel teoritik yang biasanya dibangun dengan rasionalitas relevansi dari sejumlah observed variable. Latent variable dalam penelitian dimunculkan sebagai komposit linear dari observed variables, dan disebut sebagai intervening variable dalam causal chain (Muhadjir, 2007). 


\section{Hasil dan Pembahasan}

Uji statistik penelitian, menggunakan 2 (dua) model persamaan dalam upaya menemukan pengaruh motivasi intrinsik dan ekstrinsik kerja guru, terhadap kinerja. Model persamaan digunakan sebagai model persamaan yang melibatkan variabel kompetensi sebagai variabel intervening/mediating, sehingga pada perhitungannya menggunakan path analysis.

Hasil perhitungan statistik dapat disajikan seperti dalam diagram jalur berikut:

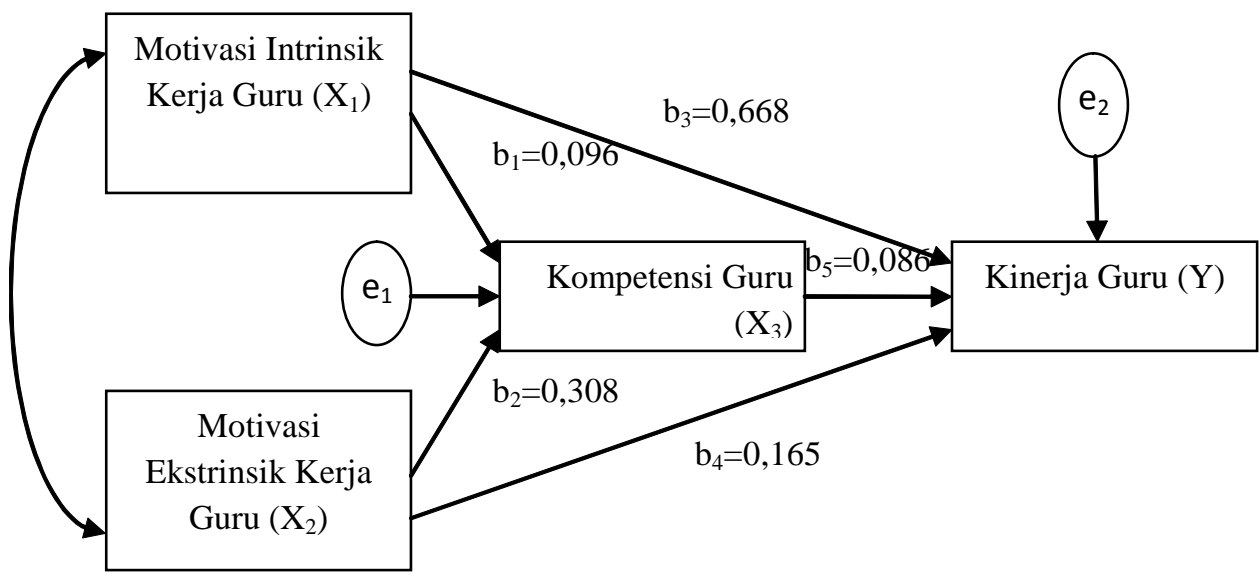

Gambar 6

Hubungan antara motivasi intrinsik kerja guru, motivasi ekstrinsik kerja guru dan kompetensi, dengan kinerja guru.

Berdasarkan hasil regresi kedua persamaan tersebut, dapat diuraikan path analysis sebagai berikut:

1. $\mathrm{X}_{1}=0,668+(0,096 \times 0,086)$

Pengaruh langsung $\mathrm{X}_{1}$ terhadap $\mathrm{Y}$ sebesar 0,668 , yang berarti bahwa semakin tinggi $\mathrm{X}_{1}$ akan meningkatkan nilai $Y$, sedangkan pengaruh tidak langsung/ mediasi $\mathrm{X}_{1}$ terhadap $Y$ sebesar 0,096 x 0,086 =0,008256, yang berarti bahwa secara tidak langsung semakin tinggi $X_{1}$ dengan mediasi/perantara $X_{3}$ akan meningkatkan Y.

Pengaruh langsung $\mathrm{X}_{1}$ terhadap $\mathrm{Y}$, sebesar 0,668 (dengan asumsi $\mathrm{R}^{2}=$ $0.446224=44,62 \%$ ) lebih besar dari pengaruh tidak langsung/mediasi $X_{1}$ terhadap $\mathrm{Y}$ yaitu sebesar 0,008256 (dengan asumsi $\mathrm{R}^{2}=0,00006816=$ $0,0068 \%$ ). Dengan demikian Total Pengaruh $\mathrm{X}_{1}$ terhadap $Y$ secara langsung 
maupun tidak langsung sebesar 0,668 +0,008256 =0,676256 (dengan asumsi $\left.\mathrm{R}^{2}=0.4573222=45,73 \%\right)$.

2. $\mathrm{X}_{2}=0,165+(0,308 \times 0,086)$

Pengaruh langsung $\mathrm{X}_{2}$ terhadap $\mathrm{Y}$ sebesar 0,165, yang berarti bahwa semakin tinggi $\mathrm{X}_{2}$ akan meningkatkan nilai $Y$ secara langsung. Sedangkan pengaruh tidak langsung $\mathrm{X}_{2}$ terhadap $\mathrm{Y}$ sebesar 0,308 x 0,086=0,026488, yang berarti bahwa secara tidak langsung semakin tinggi $\mathrm{X}_{2}$ dengan mediasi/perantara $\mathrm{X}_{3}$ akan meningkatkan Y.

Pengaruh langsung sebesar 0,165 (dengan asumsi $\mathrm{R}^{2}=0.027225=2,72 \%$ lebih besar dari pengaruh tidak langsung 0,026488 (dengan asumsi $\mathrm{R}^{2}=$ $0.0007016=0,07 \%$ ). Dengan demikian Total Pengaruh $\mathrm{X}_{2}$ terhadap $\mathrm{Y}$ secara langsung maupun tidak langsung sebesar 0,165 +0,026488 $=0.191488$ (dengan asumsi $\mathrm{R}^{2}=0.0366677=3,67 \%$ )

3. $\mathrm{X}_{3}=0,086$.

Pengaruh $\mathrm{X}_{3}$ terhadap Y sebesar 0,086, $\left(\right.$ dengan asumsi $\mathrm{R}^{2}=0,7396=$ $0.547 \%$ ). Dengan demikian secara langsung semakin tinggi $\mathrm{X}_{3}$ akan meningkatkan nilai Y.

Berdasarkan uraian hitungan path analysis menunjukkan bahwa; pengaruh langsung $X_{1}$ terhadap $Y$ sebesar 0,668 (dengan asumsi $R^{2}=0.446224=44,62 \%$ ) Lebih besar dari pengaruh tidak langsung/mediasi $\mathrm{X}_{1}$ terhadap $\mathrm{Y} 0,008256$ (dengan asumsi $\mathrm{R}^{2}=0,00006816=0,0058 \%$ ), sehingga Total Pengaruh $\mathrm{X}_{1}$ terhadap $\mathrm{Y}$ sebesar 0,668 0,008256 $=0,676256\left(\right.$ dengan asumsi $\mathrm{R}^{2}=0.4573222=45,73$ $\%$ ). Pengaruh langsung $\mathrm{X}_{2}$ terhadap $Y$ sebesar 0,165 (dengan asumsi $\mathrm{R}^{2}=0.027225$ $=2,72 \%$ Lebih besar dari pengaruh tidak langsung $\mathrm{X}_{2}$ terhadap $Y$ sebesar 0,026488 (dengan asumsi $\mathrm{R}^{2}=0.0007016=0,07 \%$ ).Dengan demikian Total Pengaruh langsung $\mathrm{X}_{2}$ terhadap $\mathrm{Y}$ sebesar $0,165+0,026488=0.191488\left(\right.$ dengan asumsi $\mathrm{R}^{2}=$ $0.0366677=3,67 \%$ ). Pengaruh langsung $X_{3}$ terhadap $Y$ sebesar 0,086 (dengan asumsi $\mathrm{R}^{2}=0.7396=0.547 \%$ ) dapat diartikan pengaruh yang muncul sebenarnya adalah pengaruh langsung searah $\mathrm{X}_{3}$ terhadap $\mathrm{Y}$ dengan pengaruh sebesar 0,086 (dengan asumsi $\mathrm{R}^{2}=07,396=3,96 \%$ ). Hasil pehitungan path analysis tersebut menunjukkan terbuktinya pengaruh $\mathrm{X}_{1}, \mathrm{X}_{2}, \mathrm{X}_{3}$ terhadap $\mathrm{Y}$. Dengan demikian total Pengaruh searah sebesar $0.4573222+0.0366677+0.07396=0.5679499$ (dengan asumsi $\mathrm{R}^{2}=0.322567088=32.25 \%$ ).

Dari hasil penelitian yang telah diuraiakan di depan, nampak beberapa hal menarik untuk dicermati lebih lanjut. Pada bagian ini akan dijelaskan lebih jauh mengenai temuan tersebut dan beberapa hal menarik lainnya yang bisa dikaji 
selanjutnya. Secara umum dapat dikemukakan bahwa semua hipotesis diterima, yaitu:

Hasil perhitungan pengaruh motivasi intrinsik kerja guru terhadap kinerja guru diperoleh berdasarkan uji yang dilakukan, menunjukkan bahwa Pengaruh langsung $\mathrm{X}_{1}$ terhadap Y, sebesar 0,668 (dengan asumsi $\mathrm{R}^{2}=0.446224=44,62 \%$ ) lebih besar dari pengaruh tidak langsung/mediasi $\mathrm{X}_{1}$ terhadap $\mathrm{Y}$ yaitu sebesar 0,008256 (dengan asumsi $\mathrm{R}^{2}=0,00006816=0,0068 \%$ ). Dengan demikian Total Pengaruh $\mathrm{X}_{1}$ terhadap Y secara langsung maupun tidak langsung sebesar 0,668 +0,008256= 0,676256 (dengan asumsi $R^{2}=0.4573222=45,73 \%$ ), yang berarti ada pengaruh searah. Sehingga semakin tinggi $X_{1}$ maka secara langsung akan meningkatkan nilai Y. Pengaruh tidak langsung sebesar 0,096 x 0,086 =0,008256, yang berarti ada pengaruh tidak langsung $X_{1}$ searah dengan adanya variabel mediasi kompetensi maka semakin tinggi $\mathrm{X}_{1}$ dengan mediasi/perantara $\mathrm{X}_{3}$ akan meningkatkan $\mathrm{Y}$ secara tidak langsung.

Hal tersebut menerangkan bahwa pengaruh langsung sebesar 0,668 lebih besar daripada pengaruh tidak langsung 0,008256, sehingga dapat diartikan pengaruh yang muncul sebenarnya adalah pengaruh langsung $\mathrm{X}_{1}$ terhadap $Y$. Namun dengan adanya kompetensi guru, maka diperoleh tingkat pengaruh yang lebih besar, yakni total Pengaruh sebesar $0,668+0,008256=0,676256$.

Hasil tersebut juga menunjukkan bahwa untuk menilai kinerja seorang guru, dapat diperhatikan pada seberapa besar motivasi intrinsik kerja guru, dengan memperhatikan kompetensi seorang guru dalam melaksanakan tugas pengajaran. Semakin tinggi motivasi intrinsik kerja guru dan kompetensi seorang guru, dapat dipastikan akan meingkatkan kinerja. Tetapi sebaliknya, jika semakin rendah motivasi Intrinsik guru dalam mengajar, dengan kompetensi yang juga rendah, secara otomatis akan menurunkan nilai kinerja secara keseluruhan.

Hasil penelitian ini sesuai dengan hasil penelitian yang dilakukan oleh Subani (2009) yang menunjukkan bahwa terdapat pengaruh positif dan signifikan faktor motivasi kerja terhadap kinerja guru. Oleh karena itu, semakin bertambah nilai faktor motivasi kerja maka semakin bertambah nilai kinerja guru. Dengan demikian maka dapat diramalkan bahwa semakin tinggi motivasi intrinsik kerja guru dan kompetensi, maka akan semakin baik pula kinerja guru tersebut dengan kata lain, diperkirakan bahwa semakin diberdayakan variabel motivasi intrinsik kerja guru dan kompetensi guru, secara bersama-sama ke arah yang positif, maka dapat diramalkan akan memberikan kontribusi yang positif pula bagi kinerja guru.

Hasil tersebut menunjukkan bahwa secara langsung dan tidak langsung motivasi intrinsik kerja guru dan kompetensi yang positif, bila dipadukan maka akan 
menghasilkan sinergi yang baik bagi pengembangan kinerja guru. Dengan meningkatkan motivasi intrinsik dan kompetensi akan meningkatkan kinerja guru dalam upaya meningkatkan kualitas pendidikan di sekolah, khususnya pada tingkatan menengah pertama di Kota Ternate Utara. Motivasi intrinsik sebagai seorang guru, akan meningkatkan dedikasi dalam melaksanakan tugas dan kewajibannya sebagai seoranng guru. Peningkatan motivasi intrinsik kerja guru, secara langsung meningkatkan keinginan guru dalam meningkatkan kompetensi guru dalam mengajar. Seorang guru yang memiliki motivasi intrinsik yang tinggi akan merasakan kenikmatan, tertarik, dan merasa senang menjalankan tugasnya. Selain itu mereka juga merasa tertantang untuk menghasilkan kinerja yang tinggi (Csikszentmihalyi, 2000; Ryan \& Deci, 2000a, Ryan \& Deci, 2000b). Semakin tinggi motivasi intrinsik kerja guru, akan mendorong peningkatan kompetensi, yang berujung pada peningkatan kompetensi seoranng guru.

Pada perhitungan pengaruh motivasi ekstrinsik kerja guru dengan hubungannya pada kompetensi, terhadap kinerja guru, diperoleh hasil perhitungan pengaruh langsung sebesar 0,165 (dengan asumsi $\mathrm{R}^{2}=0.027225=2,72 \%$ Lebih besar dari pengaruh tidak langsung 0,026488 (dengan asumsi $\mathrm{R}^{2}=0.0007016=0,07 \%$ ). Dengan demikian Total Pengaruh $\mathrm{X}_{2}$ terhadap $\mathrm{Y}$ secara langsung maupun tidak langsung sebesar $0,165+0,026488=0.191488\left(\right.$ dengan asumsi $\left.\mathrm{R}^{2}=0.0366677=3,67 \%\right)$. Ini menunjukan bahwa pengaruh motivasi ekstrinsik kerja guru terhadap kinerja guru sebesar 0,165 , yang berarti ada pengaruh searah. Semakin tinggi $X_{2}$ akan meningkatkan nilai $Y$ secara langsung maupun tidak langsung, yang berarti ada pengaruh tidak langsung $\mathrm{X}_{2}$ searah dengan adanya variabel mediasi kompetensi maka semakin tinggi $\mathrm{X}_{2}$ dengan mediasi/perantara $\mathrm{X}_{3}$ akan meningkatkan $\mathrm{Y}$ secara tidak langsung.

Hal tersebut menerangkan bahwa pengaruh langsung sebesar 0,165 lebih besar dari pada pengaruh tidak langsung 0,026488 , sehingga dapat diartikan pengaruh yang muncul sebenarnya adalah pengaruh langsung $\mathrm{X}_{2}$ terhadap $\mathrm{Y}$. Namun dengan adanya kompetensi guru, maka diperoleh tingkat pengaruh yang lebih besar, yakni total pengaruh sebesar $0,165+0,026488=0.694488$.

Hasil tersebut juga menunjukkan bahwa dalam melakukan penilaian kinerja seorang guru, tetap harus memperhatikan seberapa besar motivasi ekstrinsik kerja guru, dengan memperhatikan kompetensi seorang guru dalam melaksanakan tugas pengajaran (Ryan \& Deci, 2000a, Ryan \& Deci, 2000b). Semakin tinggi motivasi ekstrinsik kerja guru dan kompetensi seorang guru, dapat dipastikan akan meningkatkan kinerja. Tetapi sebaliknya, jika semakin rendah motivasi ekstrinsik guru dalam mengajar, dengan kompetensi guru yang juga rendah, secara otomatis 
akan menurunkan nilai kinerja guru secara keseluruhan. Motivasi ekstrinsik kerja guru, terkait dengan berbagai faktor lingkungan yang ada di sekitar guru. Semakin kondusif lingkungan dalam memandang motivasi guru dalam menjalankan tugas dan fungsinya, tentu akan meningkatkan kompetensinya dalam melaksanakan tugas dan kewajibannya. Selanjutnya, semakin tinggi motivasi ekstrinsik yang mendorong kompetensi guru, maka akan meningkatkan kinerja guru secara menyeluruh.

Hasil perhitungan dalam persamaan kedua, melibatkan kompetensi guru sebagai faktor laten yang memediasi hubungan variabel $\mathrm{X}_{1}$ dan $\mathrm{X}_{2}$ terhadap kinerja guru ( $\mathrm{Y}$ ). Pengaruh $\mathrm{X}_{3}$ secara langsung terhadap $\mathrm{Y}$ sebesar 0,086 (dengan asumsi $\mathrm{R}^{2}=0,7396$ $=0.547 \%$ ). Dengan demikian semakin tinggi $\mathrm{X}_{3}$ akan meningkatkan nilai $\mathrm{Y}$ secara langsung, yang berarti ada pengaruh searah $\mathrm{X}_{3}$ terhadap $\mathrm{Y}$, maka Semakin meningkat $\mathrm{X}_{3}$ akan meningkatkan nilai Y juga. Hasil tersebut berarti bahwa kompetensi guru merupakan instrumen yang memang mampu memberikan peningkatan layanan sekolah lebih baik kepada siswa, melalui kinerja seorang guru.

Berdasarkan uraian hitungan path analysis menunjukkan bahwa; pengaruh langsung $\mathrm{X}_{1}$ terhadap $Y$ sebesar 0,668 (dengan asumsi $\mathrm{R}^{2}=0.446224=44,62 \%$ ) lebih besar dari pengaruh tidak langsung/mediasi $\mathrm{X}_{1}$ terhadap $\mathrm{Y}$ 0,008256 (dengan asumsi $R^{2}=0,00006816=0,0058 \%$ ), sehingga Total Pengaruh $X_{1}$ terhadap $Y$ sebesar 0,668 +0,008256 $=0,676256\left(\right.$ dengan asumsi $\left.R^{2}=0.4573222=45,73 \%\right)$. Pengaruh langsung $\mathrm{X}_{2}$ terhadap $\mathrm{Y}$ sebesar 0,165 (dengan asumsi $\mathrm{R}^{2}=0.027225=$ $2,72 \%$ lebih besar dari pengaruh tidak langsung $\mathrm{X}_{2}$ terhadap $Y$ sebesar 0,026488 (dengan asumsi $\mathrm{R}^{2}=0.0007016=0,07 \%$ ). Dengan demikian Total Pengaruh langsung $\mathrm{X}_{2}$ terhadap $\mathrm{Y}$ sebesar $0,165+0,026488=0.191488$ (dengan asumsi $\mathrm{R}^{2}$ $=0.0366677=3,67 \%)$. Pengaruh langsung $X_{3}$ terhadap $Y$ sebesar 0,086 (dengan asumsi $\mathrm{R}^{2}=0.7396=0.547 \%$ ) dapat diartikan pengaruh yang muncul sebenarnya adalah pengaruh langsung searah $\mathrm{X}_{3}$ terhadap $\mathrm{Y}$ dengan pengaruh sebesar 0,086 (dengan asumsi $\mathrm{R}^{2}=07,396=3,96 \%$ ). Hasil pehitungan path analysis tersebut menunjukkan terbuktinya pengaruh $\mathrm{X}_{1}, \mathrm{X}_{2}, \mathrm{X}_{3}$ terhadap Y. Dengan demikian total Pengaruh searah sebesar $0.4573222+0.0366677+0.07396=0.5679499$ (dengan asumsi $\mathrm{R}^{2}=0.322567088=32.25 \%$ ).

Berdasarkan hasil perhitungan analisis jalur di atas menunjukkan bahwa kompetensi guru merupakan variabel intervening bagi motivasi intrinsik dan ekstrinsik. Kompetensi guru yang baik, akan memberikan pengaruh positif pada berbagai pelaksanaan fungsi dan tugas seorang guru (Youn Chyung, Stepich, \& Cox, 2006). Temuan ini mengungkapkan bahwa kompetensi guru merupakan faktor yang turut mempengaruhi kinerja guru. Sebagaimana yang telah dikemukakan pada kajian 
teoretis, kompetensi sangat berpengaruh terhadap kinerja seseorang (Van der Klink, \& Boon, 2002; Sandberg, 2000). Kompetensi seseorang entah positif atau negatif cenderung mempengaruhi kinerja orang tersebut. Bila kompetensi orang positif atau memadai maka kinerja akan cenderung positif. Sebaliknya bila kompetensi negatif atau tidak memadai maka kinerjanya akan cenderung negatif(Montier, Alai, \& Kramer, 2006; Teodorescu, 2006).

Peningkatan kompetensi seorang guru, mendukung motivasi intrinsik dan ekstrinsik kerja guru dalam meningkatkan kinerja guru. semakin baik kompetensi guru, maka secara tidak langsung akan menambah pengaruh positif pada motivasi kerja yang berujung pada peningkatan kinerja guru yang lebih baik. Hal tersebut menunjukkan betapa pentingnya kompetensi seorang guru, demi diperolehnya kinerja seoranng guru yang memiliki kinerja guru terbaik.

\section{Simpulan}

Kompetensi guru merupakan instrumen yang memang mampu memberikan peningkatan layanan sekolah lebih baik kepada siswa, melalui kinerja guru. Kompetensi guru yang baik, akan memberikan pengaruh positif pada berbagai pelaksanaan fungsi dan tugas seorang guru. Hasil temuan ini mengungkapkan bahwa kompetensi guru merupakan faktor yang turut mempengaruhi kinerja guru.

\section{Daftar Pustaka}

Csikszentmihalyi, M. (2000). Beyond boredom and anxiety: Experiencing flow in work and play. (2 ${ }^{\text {nd }}$ ed) San Francisco: Jossey Bass.

Depdiknas. (2003). Undang-Undang RI nomor 20 tahun 2003 tentang sistem pendidikan nasional.

Depdiknas. (2005). Undang-undang RI nomor 14 tahun 2005 tentang guru dan dosen.

Depdiknas. (2005). Peraturan pemerintah RI nomor 19 tahun 2005 tentang standar nasional pendidikan.

Ghozali, I. (2009). Aplikasi analisis multivariate dengan program SPSS. Semarang: Badan Penerbit Undip.

Montier, R., Alai, D., \& Kramer, D. (2006). Measuring and evaluating: Competency models Develop top performance. Training and Development, 3, 4750. 
Muhadjir, N. (2007). Metodologi keilmuan. Yogyakarta: Rake Sarasin.

Ridwan. (2009). Metode \& teknik menyusun proposal penelitian, Bandung: Alfabeta.

Ryan, R.M., \& Deci, E.L. (2000a). Self-determination theory and the facilitation of intrinsic motivation, social development, and well-being. American Psychologist, 55,68-78.

Ryan, R.M., \& Deci, E.L. (2000b). Intrinsic and extrinsic motivations: Classic definitions and new directions. Contemporary Educational Psychology, 25, 54-67. doi:10.1006/ceps.1999.1020. 